\title{
Introduction: Why Should Political Theorists Care About Work?
}

\section{Ben Turner \& Lucas Van Milders}

\author{
This is an author accepted manuscript of an article forthcoming in Theory \& Event, published by John Hopkins \\ University Press.
}

\section{Abstract}

Even though the future of work has become a significant public concern, political theory has not yet considered work to be a central concept within the discipline. The five papers in this symposium provide a range of perspectives on what it means to take work seriously within political thought. This introduction will give an account of why work should be considered as important by political theorists, contextualize the broader landscape into which these papers intervene (characterized by the issues of automation, precarity, and social reproduction), and situate them within existing writing on work within political theory.

Work takes up the vast majority of our lives. Despite this fact, work is a topic that has been largely neglected by political theorists. This is not simply a problem because of the proportion of our time that it occupies, but because work possesses characteristics that are integral to many of the themes of political theory. Commentators who have addressed this gap have argued that political theory's neglect of work means it fails to consider the dominant manner in which the obligation to work integrates individuals into "the basic social contract" of liberal democracies. ${ }^{1}$ If the substance of political theory is how these processes of integration are governed, then work should be of central importance. Moreover, work plays more than a sociological role. It constitutes a directly political relationship in which our choices are governed by others. Although it appears to be part of the public realm, employment is in reality a form of "private" government with ensuing trade-offs regarding our freedom. ${ }^{2}$ Freedom and its relationship to government is arguably the bread and butter of much political theory, yet work is absent from most discussions of this relationship. It is granted that Marxist and Feminist traditions have indeed considered work as a central element of political thought, but the absence of these themes across political theory of all traditions - such as analytical and continental schools more broadly_is clear.

This lacuna could be explained as a product of intellectual history. Post-Marxism transformed the class- and thus work-based analyses of Marxism into a consideration of the political dynamics of identity beyond class. ${ }^{3}$ Work loses importance as an object of concern for left-wing political thought precisely because it must compete with a variety of other concerns that do not map onto the working class as a subject. In a manner similar to and not totally distinguishable from post-Marxism, continental political philosophy has largely been concerned with the abstractions of post-foundational or post-structural ontological reasoning in order to theorize the changing and fractured nature of identity and community over the concrete realities of working life, especially under the auspices of neoliberal modes of government. ${ }^{4}$ This is a concern that arises from a skepticism of authority, and thus of assertive and strictly normative politics that one might associate with class and work-based organization, which lies partially in the continental tradition's roots in the 1968 student movements. Liberal egalitarianism — and its considerations of distribution, justice, and rights - has focused its attention on the moral principles that underlie the redistribution of goods rather than the realities of the market economies that produce the inequalities that they are intended to address. ${ }^{5}$ Analyses of justice without any consideration of work are the product of a long move away from the circumstances of individual lives, as figures like Charles W. Mills have claimed. ${ }^{6}$ Crucially, these circumstances are defined by a range of relationships to work.

Times are changing, however. Since the global financial crash of 2007-'08 and the austerity that followed it - the joint consequence of which has been a growth of both inequality and precarity, as well as a growing concern for the impact of technological progress on employment that may compound these problems-work has gained traction as a key topic of interest. Popular accounts of the potential impact of these developments have proliferated in recent years, many of which invoke direct consequences for freedom and democracy. ${ }^{7}$ Campaigns for a post-work society have drawn on these insights to suggest that they present an opportunity to challenge both the necessity of full-time employment and the work ethic more generally. ${ }^{8}$ A four-day working week, variations on a universal basic income, and new models of public and worker ownership are common proposals in this area. ${ }^{9}$ The pressing nature of these concerns have been highlighted by responses to the COVID-19 pandemic in the world of work. These indicate both 
the possibility of radically rethinking how we organize, value, and remunerate work, and the extent to which existing inequalities in this sphere are entrenched. Disparities between those who have been able to shift work to a safer setting at home and those who have no choice but to work in unsafe conditions are a clear indicator of the deeply political nature of work.

Notwithstanding notable exceptions, political theory has generally been slow to respond to these developments by integrating work into its central concerns. ${ }^{10}$ The aim of this symposium is to highlight both why work should be a topic of central importance for political theory and how political theory might contribute to contemporary discussions regarding the nature and place of work. Crucially, the articles here do not hew to one particular school of thought in order to demonstrate the pertinence of work to political theory as a whole. Approaches represented include Feminism, Marxism, Republicanism and Decolonial Theory. Less-prominent traditions that have been more attentive to work than mainstream political theory are also brought to the fore in order to demonstrate their importance to political theory more widely: labor Republicanism, ${ }^{11}$ feminist discussions of sex work, ${ }^{12}$ and Social Reproduction Theory ${ }^{13}$ in particular. In what follows, we will outline some of the central influences on, and themes within, the turn to work in order to situate the articles of this symposium in this wider context. ${ }^{14}$

\section{Automation}

Automation and its potential impact upon employment is one of the most immediately visible and discussed topics concerning the future of work. News publications that have not published on this issue are the exception to a gamut of op-eds and analyses of how developments in artificial intelligence, machine learning, and robotics will transform the workforce. Commonly repeated narratives on this theme share a concern for the discovery that non-routine and cognitive tasks could be performed by machines, in contrast to existing assumptions that only routine and noncognitive labor can be automated. ${ }^{15}$ Consequently, advances in machine learning suggest a massive expansion of the number of jobs that could potentially be subject to automation. Job polarization and underemployment (rather than unemployment) are perceived to be the consequences of this trend. ${ }^{16}$ Traditionally middle-class jobs - which involve non-manual and non-routine work, but at a relatively low level of complexity-are in danger of being hollowed out, leaving a gap between work that is difficult to automate because it requires "high skill" cognitive abilities or "low skill" tasks that involve tacit, fiddly, and habitual knowledge. Think of the discrepancy in salary between a successful lawyer and a cleaner or service worker; it is the managerial and secretarial work in between these two extremes that is most in danger of being eradicated by automation. ${ }^{17}$ As such, automation is perceived to have the potential to overturn the class dynamics of the Western world due to the central role that the middle classes apparently play in democratic politics. ${ }^{18}$

Whether these predictions are realistic or fantastical is somewhat beside the point, given that they have galvanized a range of discussions about the nature of work on the basis of their mere possibility. These responses are, somewhat unsurprisingly, mixed. As stated, some perceive this as an opportunity to challenge our relationship with work, and to use automation to reduce working time and increase the leisure time required for an autonomous and fulfilling life beyond capitalism. ${ }^{19}$ Others are less ambitious, and seek to reconcile automation with existing models of growth and employment. ${ }^{20}$ Both of these positions accept the claim that automation will transform the economy. Skeptics look to other causes for pressures on employment, such as low productivity, and see "automation discourse" as missing the forest for the trees. ${ }^{21}$ Whether automation does pose an immediate threat to employment or not, responses to its possibility present a rich seam for political theorists to mine insofar as the reflection on work and the changes it might bring upon society are revealing of our assumptions about both what should be and what justifies what $i$.

In the context of automation, thinking about work has consequences for normative discussions that reach beyond the immediate realm of employment. The substance of these reflections on work have already been subject to some scrutiny in this respect. Most generally, it has been noted that power is absent from many accounts of post-work politics. Technology should not be understood as an inexorable, society-changing force, but as dependent upon existing relations of power and the normative assumptions behind them. ${ }^{22}$ Forces of production that are necessary for the automation revolution are embedded within global class dynamics and the relations of production that they entaila reality which is obscured by techno-utopianism. ${ }^{23}$ Technological transformation alone will not alter these relations. Neither will it disrupt gendered and racialized inequalities without explicit consideration of the relations that underpin them. ${ }^{24}$ For example, images of automated futures can reproduce racial inequalities regarding who should be served and who is servile, and the promotion of a universal basic income to respond to technological unemployment will do little to address gendered divisions of labor both in the workplace and in the home without thinking about the social 
basis of these inequalities. ${ }^{25}$ Political theorists should be attentive to these issues because they require the projection of new normative claims regarding work and the unearthing of the assumptions which underlie our existing ones.

One substantive normative commitment that has been rethought in the context of automation is freedom. Recent work within Republican political thought has sought to recover the insights of radical and labor republicanism for the contemporary place of work. In "Radical Republicanism and the Future of Work," Tom O'Shea argues that the restructuring of the workforce that automation is precipitating provides an occasion to challenge models of work that presuppose the subordination of workers. Subordination, or domination, is understood in terms of a worker's lack of economic freedom, i.e. their lack of access to the economic capabilities necessary to stand in relationships of civil equality. As a theory that opposes arbitrary power and economic servitude, Republican theory is ideally placed to offer ways of resisting the arbitrary (economic) domination of workers. Enhancing worker power through workplace organization, providing access to economic goods and services, and enhancing the importance of leisure are but some of the potential strategies that emanate from this perspective. Arguing that this applies to paid, productive work as well as unpaid, reproductive work, O'Shea concludes that radical Republicanism's understanding of freedom offers a rationale for a reduction of work, which in turn frees up more time and energy for self-development as well as a reason for transforming work altogether.

Automation has also prompted reflection on the relation between freedom and work in the home. Gendered forms of social reproduction are often taken for granted in post-work imaginaries based on automation, while it is clear that automation in the workplace does not necessarily lead to the reduction of work in the home. It is in this context that Valeria Graziano and Kim Trogal argue that feminist critiques of domestic technologies ought to be seen as facilitating anti-work instead of post-work imaginaries. In "On Domestic Fantasies and Anti-Work Policies: A Feminist History of Complicating Automation," they argue that post-work perspectives typically lack an analysis of the domestic realm and thereby ignore the well-known feminist challenge to the arbitrary separation of the public and the private sphere: the home is not autonomous from capital. Graziano and Trogal focus their analysis on the notion that automated technology is inherently labor-saving. Reflecting on the Taylorization of the housewife and the rationalizing of the working-class home, they highlight how the domestic sphere is also subject to the pervasive language of productivity. Free time has not facilitated a woman's own leisure or development, but has instead contributed to the increased individualization of work, whereby each housewife was supposed to self-Taylorize and perform all tasks. As an alternative, Graziano and Trogal present a radical reading of amateurism, leisure, and hobbies as sites where practices abandon their productive capacities and can generate new life worlds.

\title{
Precarity
}

One consequence of automation is the fragmentation and disruption of the labor market. Here technological development both facilitates and exacerbates the second key concern that motivates a return to the question of work in political theory: precarity. Automation and its impact on the workforce exacerbates the ongoing undermining of secure employment by precarious forms of work, which is defined as follows:

\begin{abstract}
Precarious work is best defined as the absence of those aspects of the standard employment relationship (SER) that support the decommodification of labor...the essence of the SER is found not in its habitual form of full-time permanent work but in its substantive protections against a pure market relationship, jointly provided by employers and the state through employment rights and social protection...Precarious work, in contrast, is associated with low pay, insufficient and variable hours, short-term contracts and limited social protection rights. These characteristics are frequently found in, but not confined to, what are known as non-standard forms of employment (NSFE), including part-time, temporary and zero hours contracts and dependent self-employment. ${ }^{26}$
\end{abstract}

A word of caution is necessary here. Precarious forms of work are not new. Vulnerability to precarious work has always been a pressing issue for those falling on the "wrong side" of how the labor market is carved up, particular in terms of race, gender or migration status. ${ }^{27}$ Moreover, attention to precarity within the Western world should be situated with respect its place in a global history of insecure employment and dispossession by capital. ${ }^{28}$ In this respect secure employment is an historical exception rather than a norm from which we have only recently deviated. What is new however, is the expansion of the employment practices that have underpinned precarious work to hitherto "stable" areas of employment traditionally occupied by the white middle classes ${ }^{29}$ - to the extent that some have defined the precariat as a new, universal class. ${ }^{30}$ 
Such a claim is made in response to several aspects of precariousness, of which we highlight two key developments. First, standard employment relationships have not only been replaced by non-standard forms of employment but precarious forms of employment practices have become a regular aspect of standard employment. From the 1970s onwards, increased precarity has resulted from neoliberal transformations within Western economies that have shifted power from labor to capital. ${ }^{31}$ In other words, precarity in the realm of work is a product of the employment practices specific to neoliberalism as a regime of capital accumulation. As a reinstitution of class war against labor, neoliberalism leverages government against labor by deregulating employment in order to facilitate flexibility in production and push down costs, particularly those associated with standard employment relationships. Another reason why political theorists should pay attention to work, then, is that precarity represents a relationship between employment and governance that supersedes one characterized by the exchange of obedience for protection. ${ }^{32}$ This highlights the extent to which the problem of liberty is at stake in the employment relationship insofar as it is one of private government and certainly one in which the employee has little power in the majority of cases. ${ }^{33}$

Precarity does not simply hold power over individuals with respect to their employment. Existing work has highlighted a second development that is central to precarity: it expands well beyond the employment relationship, insofar as precarious work puts pressures on personal, familial, and household life. In an employment environment dominated by precarity, success becomes available to those that can adopt an entrepreneurial mindset in order to navigate a range of, sometimes simultaneously, insecure, temporary, and low-wage contracts. ${ }^{34} \mathrm{~A}$ central pillar of neoliberalism is this personal responsibility. You, and not the state, are responsible for your ability to compete with others in order to work and provide for yourself and your dependents. ${ }^{35}$ Those that cannot do so are forced to fall back upon other solutions such as payday loans to bridge the gap between paychecks. Precarity at work is thus linked to a more generalized state of precarity represented by the financialization of everyday life that is characterized by the centrality of debt to economic survival. ${ }^{36}$ Changes to secure forms of employment are integrated within wider relationships between precarity and the state, individuals, and social expectations regarding work.

It should be noted that precarity has been subject to criticism due to its nebulous character. It describes a huge range of human experience and is as such considered by some to be conceptually diffuse. ${ }^{37}$ Regardless of this, precarity is still important for highlighting the significance of work to political theorists. As a concept, precarity at least attempts to capture a set of transformations in the world of work that have significant consequences for themes that are common objects of attention for political theorists. Deregulation of the labor market represents the state's active role in determining the nature of employment relationships, and thus the nature of private government. Precarity transforms the way in which individuals encounter the state through its regulation of work, but also the power relationships that constitute private governance. The power to voice one's disagreement and to exit a relationship of private governance are negated if that employment is precarious. Political theorists would do well to ask how precarity as a particular regime of work is pertinent to common concerns of political thought, such as justice, equality, and liberty.

However, as mentioned above, precarity is nothing new. It can and should be related to existing relations of colonial and racial violence. In "Precarity/Coloniality," Lucas Van Milders retraces the colonial histories and realities that continue to structure discussions and experiences of precarity today. This is related to the racialized and gendered nature of precarity as well as the fact that its discussion has become widespread at the exact moment that precaritization has captured the once-privileged subject of colonial subjugation and capitalist extraction: the middle-class, white male. Most importantly, the whiteness of precarity continues to structure popular post-work imaginaries that are steeped in Western experiences and narratives. Drawing on Autonomist anti-work resistances in the form of Autonomia and Zapatismo, Van Milders concludes that discussions on the future of work will maintain their relevance and efficacy only by critically reflecting on the role that colonial and racial violence plays in shaping and maintaining experiences of precarity today.

\section{Reproduction, Care, and Sex Work}

Automation has the potential to transform the nature of employment and precarity is seen to have already wrought significant changes upon standard employment relationships. Consequently, the changing nature of work provides the opportunity for hitherto fringe considerations of neglected forms of work to be brought to the center of political theory. These are forms of labor that have been deemed as unproductive and therefore not truly work (such as care labor) and those that are not seen to be morally justifiable and therefore cannot be sanctioned as labor (such as sex-work). ${ }^{38}$ Social reproduction theorists have long criticized the distinction between so called productive employment and private care labor in the home. While care work is not directly "productive," insofar as it does not produce surplus value, 
without the reproduction of the worker and the social structures that facilitate their ability to work, there is no production of surplus value. Care work is thus directly implicated within the process of accumulation and is as much a site of exploitation as the workplace. ${ }^{39}$ Precisely how care work is implicated in the production of surplus value is a contentious question, however a point shared by social reproduction theorists is that it is a neglected area of the analysis of the politics of labor. ${ }^{40}$

Expanding and drawing upon the wages-for-housework activism of feminist movements in the "70s, attention to social reproduction brings gender to the center of the political theory of work. There are two reasons for this. First, it highlights the way in which a gendered division of labor is integral to, rather than a mere epiphenomenon of, current conceptualizations of work. As Silvia Federici summarizes, the ideology of work mobilized by capital requires this naturalization of female care labor:

\begin{abstract}
The difference with housework lies in the fact that not only has it been imposed on women, but it has been transformed into a natural attribute of our female physique and personality, an internal need, an aspiration, supposedly coming from the depth of our female character. Housework was transformed into a natural attribute, rather than being recognized as work, because it was destined to be unwaged. Capital had to convince us that it is a natural, unavoidable, and even fulfilling activity to make us accept working without a wage. ${ }^{41}$
\end{abstract}

Second, it draws our attention to how changes in the realm of work exert pressure upon this particular division of labor. It is unlikely that automation or other technological developments will substantially alleviate the burden of housework on their own. ${ }^{42}$ Feminists have long argued that technology does not alleviate "domestic drudgery in any straightforward way." ${ }^{33}$ Similarly, precarity and downward pressure on wages have made the need for two-income households more pressing while the gendered division of labor in the home has largely stayed the same. ${ }^{44} \mathrm{~A}$ rise in women joining the public workforce has been facilitated by precarious labor performing care labor as a service. This is not a new phenomenon; care labor as a service has long been racialized and performed by those at the sharp end of precarity. ${ }^{45}$ Moreover, injustices and inequities that are distributed along racial lines are compounded by the dual caring burden of the care-worker-mother. ${ }^{46}$ Racialized and gendered relations of power have been at the center of much critical political theory, and the consideration of care work within social reproduction theory provides another avenue to pursue these analyses. ${ }^{47}$

The gendered dynamics of care labor are also present within considerations of sex work. Sex work's place as an object of concern for feminists is a vexed issue. ${ }^{48}$ For some, sex work is simply part of patriarchal control over women's lives and bodies. ${ }^{49}$ For others, the refusal to see sex work as a legitimate form of labor prevents a consideration of how this form of work involves a unique set of intersecting forces—such as race, gender, and sexuality-which combine to create distinct forms of both freedom and oppression. ${ }^{50}$ If choices to engage in sex work are contextualized within the economic and social conditions that inform these decisions (as opposed to simply oppression), then it can be understood as a particular form of work that is subject to pressures that might render it as oppressive without it necessarily being so. ${ }^{51}$ Insofar as such choices, or indeed their absence, are informed by economic inequalities, hierarchies, and gendered and racialized power relations, sex work should be understood as a specific form of work in which these pressures converge in a particular manner, but also as subject to pressures that are present in all work in some form. ${ }^{52}$ Consequently, through a consideration of sex work, political theorists might gain access to hitherto fringe discussions about the nature of power, freedom, and oppression and how these issues inform the choices individuals make about the forms of work that they choose to engage in.

Social reproductive labor and sex work are of importance to the political theorist because they allow both for an expanded understanding of the forms that work might take, as well as the exertion of, and challenges to, power relations that might exist in what have hitherto been considered as fringe realms of work relations. Moreover, accounts of justice in political theory often hinge upon the question of how to properly address injustices, and give a voice to those suffering from them, if they are not immediately visible. If care work and sex work have been rendered "invisible" by conceptualizations of work that exclude labor perceived as unproductive or morally unacceptable, then the task of making the problems of these forms of work visible falls under the auspices of considerations of justice. ${ }^{53}$ This insight, drawn from accounts of socially reproductive labor and sex work, applies beyond these realms of work. What we define as valuable labor has an impact on what kinds of work are "visible" and "invisible" to the political theorist, and therefore also impacts what political problems they pose. 
One such form of invisible, or at least unclearly defined, form of labor is intellectual production. The nature of the cooption of indirectly productive labor is at stake in David Bates's discussion of the exploitation of academic work in "Academic Labor and its Exploitation." Bates inquires into the character of the exploitation of academic labor if it is not considered directly productive and is therefore in some way "invisible." By way of a discussion of Marxist debates regarding membership of the working class and the source of value, Bates argues that academic labor should be considered as a form of mediated production. It is not directly productive of surplus value but mobilizes caring and affective labor in order to indirectly produce value through the training of future workers. Insofar as academic work that is beyond measure is subjected to the rule of measure, and therefore the source of surplus value, it can be considered as exploited.

It is, in the end, through discussions of neglected forms of work that we can get a better sense of why it matters that a given activity is defined as work or not, and what this indicates about the meaning of work itself. This claim is central to Amelia Horgan's contribution. In "Creeping and Ameliorative Accounts of 'Work'," Horgan argues that claiming an activity as work can change the meaning of work. By looking at sex work and emotional labor, Horgan clarifies how feminist theory has contributed to the reconceptualization of work as both a social and legal institution and a terrain of social meaning. These accounts of work allow us to get a better sense of the plurality of individual experiences of work as they foreground the complicated relationship between exploitation and conscious activity rather than unproblematically accepting any one critical or laudatory definition of work. Work is a category that is fundamentally pluralist in Horgan's view.

It is this pluralism that this collection seeks to foster. Political theorists should not be urged to consider work as part of their broader theoretical concerns in any one particular manner. Instead, the diversity of ways in which work can be defined and the range of issues in which it appears as a concern - such as automation, precarity, and care and sex work - suggest that it would be intellectually unproductive to stipulate precisely what work is and why it poses pressing theoretical questions. It is the contention of this symposium that approaching work from a range of theoretical perspectives, as do the pieces included here, is central for developing how political theory as a discipline might address the problems and concerns it raises.

Notes

${ }^{1}$ Kathi Weeks, The Problem with Work Feminism, Marxism, Antiwork Politics, and Postwork Imaginaries (Durham, NC: Duke University Press, 2011), 8.

${ }^{2}$ Elizabeth Anderson, Private Government: How Employers Rule Our Lives (and Why We Don't Talk about It) (Princeton, NJ: Princeton University Press, 2017).

${ }^{3}$ See Ellen Meiksins Wood, The Retreat from Class: A New 'True' Socialism (London: Verso, 1987).

${ }^{4}$ For a version of this critique from within the continental tradition see: Bernard Stiegler, "The Pharmacology of PostStructuralism: An Interview with Bernard Stiegler," in The Edinburgh Companion to Post-Structuralism, ed. Benoît Dillet, Iain Mackenzie, and Robert Porter (Edinburgh: Edinburgh University Press, 2013), 490. Stiegler represents an exception within this tradition due to his explicit focus on the issue of work in Automatic Society Vol.1: The Future of Work, trans. Daniel Ross (Cambridge, UK: Polity, 2016).

${ }^{5}$ Katrina Forrester, In The Shadow of Justice: Postwar Liberalism and the Remaking of Political Philosophy (Princeton, NJ: Princeton University Press, 2019), 124.

${ }^{6}$ Charles W. Mills, "Ideal Theory as Ideology," in Black Rights/White Wrongs: The Critique of Racial Liberalism (Oxford, UK: Oxford University Press, 2017), 72-90.

${ }^{7}$ E.g. Peter Frase, Four Futures: Life After Capitalism (London: Verso, 2016); Carl Benedikt Frey, The Technology Trap: Capital, Labor, and Power in the Age of Automation (Princeton, NJ: Princeton University Press, 2019); Andrew McAfee and Erik Brynjolfsson, The Second Machine Age: Work, Progress, and Prosperity in a Time of Brilliant Technologies (New York: W.W. Norton and Company, 2014).

${ }^{8}$ John Danaher, Automation and Utopia: Human Flourishing in a World without Work (Cambridge, MA: Harvard University Press, 2019); David Frayne, The Refusal of Work: The Theory and Practice of Resistance to Work (London: Zed Books, 2015); Frase, Four Futures; Lynne Pettinger, What's Wrong with Work? (Bristol, UK: Bristol University Press, 2019); Mareile Pfannebecker and J.A. Smith, Work Want Work: Labor and Desire at the End of Capitalism 
(London: Zed Books, 2020); Nick Srnicek and Alex Williams, Inventing the Future: Postcapitalism and a World Without Work (London: Verso, 2015).

9 For example, Autonomy (https://autonomy.work/about-us/) and Common Wealth (https://www.commonwealth.co.uk).

${ }^{10}$ See Anderson, Private Government; James A. Chamberlain, Undoing Work, Rethinking Community: A Critique of the Social Function of Work (Ithaca, NY: ILR Press, 2018); Nichole Marie Shippen, Decolonizing Time: Work, Leisure, and Freedom (London: Palgrave Macmillan, 2014); Weeks, The Problem with Work.

${ }^{11}$ E.g. Elizabeth Anderson, "Equality and Freedom in the Workplace: Recovering Republican Insights," Social Philosophy and Policy 31, no. 2 (2015): 48-69; Alex Gourevitch, "Labor Republicanism and the Transformation of Work," Political Theory 41, no. 4 (2013): 591-617; From Slavery to the Cooperative Commonwealth: Labor and Republican Liberty in the Nineteenth Century (Cambridge, UK: Cambridge University Press, 2015); Tom O'Shea, “Are Workers Dominated?", Journal of Ethics and Social Philosophy 16, no. 1 (2019): 1-24.

${ }^{12}$ Brooke Meredith Beloso, "Sex, Work, and the Feminist Erasure of Class," Signs: Journal of Women in Culture and Society 38, no. 1 (2012): 47-70; Juno Mac and Molly Smith, Revolting Prostitutes: The Fight for Sex Worker's Rights (London: Verso, 2020).

${ }^{13}$ For an excellent overviews of recent and historical debates within Social Reproduction Theory see, respectively: Tithi Bhattacharya, ed., Social Reproduction Theory: Remapping Class, Recentering Oppression (London: Pluto Press, 2017); Susan Ferguson, Women and Work: Feminism, Labor and Social Reproduction (London: Pluto Press, 2020).

${ }^{14}$ Many of the pieces in this symposium began as presentations given in the "The Future of Work" seminar series at the University of Kent and at the "Political Theory and the Future of Work" workshops held at the Manchester Workshops in Political Theory by MANCEPT. The authors thank both the School of Politics and International Relations at Kent for its financial support of these seminars and the organizers at MANCEPT.

${ }^{15}$ Daron Acemoglu and Pascual Restrepo, "Automation and New Tasks: How Technology Displaces and Reinstates Labor," Journal of Economic Perspectives 33, no. 2 (2019): 3-30; Carl Benedikt Frey and Michael A. Osborne, "The Future of Employment: How Susceptible Are Jobs to Computerization?", Technological Forecasting and Social Change 114 (2017): 254-80.

${ }^{16}$ Frey, The Technology Trap, 246.

${ }^{17}$ Richard Susskind and Daniel Susskind, The Future of the Professions: How Technology Will Change the Work of Human Experts (Oxford, UK: Oxford University Press, 2015).

${ }^{18}$ Frey, The Technology Trap, 264-65.

${ }^{19}$ Danaher, Automation and Utopia; Srnicek and Williams, Inventing the Future; Stiegler, Automatic Society.

${ }^{20}$ Frey, The Technology Trap; McAfee and Brynjolfsson, The Second Machine Age.

${ }^{21}$ Aaron Benanav, "Automation and the Future of Work-1," New Left Review 119 (2019): 5-38; "Automation and the Future of Work-2," New Left Review 120 (2019): 117-46; Automation and the Future of Work (London: Verso, 2020); Astra Taylor, "The Automation Charade," Logic, 1 August 2018, accessed April 3 2020, https://logicmag.io/failure/the-automation-charade/; Judy Wajcman, “Automation: Is It Really Different This Time?", The British Journal of Sociology 68, no. 1 (2017): 119-127.

${ }^{22}$ David Spencer, "Work in and beyond the Second Machine Age: The Politics of Production and Digital Technologies," Work, Employment and Society 31, no. 1 (2017): 142-52; "Fear and Hope in an Age of Mass Automation: Debating the Future of Work," New Technology, Work and Employment 33, no. 1 (2018): 1-12.

${ }^{23}$ e.g. Nick Dyer-Witheford, Cyber-Proletariat: Global Labor in the Digital Vortex (London: Pluto Press, 2015), 10323.

${ }^{24}$ Ben Turner, "“Above and Beyond the Market': The Family, Social Reproduction and Conservatism in Bernard Stiegler's Politics of Work," Angelaki: Journal of the Theoretical Humanities (forthcoming).

${ }^{25}$ Respectively, Neda Atanasoski and Kalindi Vora, Surrogate Humanity: Race, Robots, and the Politics of Technological Futures (Durham, NC: Duke University Press, 2019); Debra Howcroft and Jill Rubery, “"Bias in, Bias out': Gender Equality and the Future of Work Debate," Labor \& Industry: A Journal of the Social and Economic Relations of Work 29, no. 2 (2019): 213-27.

${ }^{26}$ Jill Rubery et al., "Challenging Contradictions in the "Normalizing" of Precarious Work," Work, Employment and Society 32, no. 3 (2018): 510. 
${ }^{27}$ Arne L. Kalleberg, "Precarious Work, Insecure Workers: Employment Relations in Transition," American Sociological Review 74, no. 1 (2009): 10; Bridget Anderson, "Migration, Immigration Controls and the Fashioning of Precarious Workers," Work, Employment and Society 24, no. 2 (2010): 300-317.

${ }^{28}$ Ronaldo Munck, "The Precariat: A View From the South," Third World Quarterly 34, no. 5 (2013): 747-762.

${ }^{29}$ Dyer-Witheford, Cyber-Proletariat, 159.

${ }^{30}$ Guy Standing, The Precariat: The New Dangerous Class (London: Bloomsbury, 2011).

${ }^{31}$ David Harvey, A Brief History of Neoliberalism (Oxford, UK: Oxford University Press, 2005).

${ }^{32}$ As developed by Isabelle Lorey, State of Insecurity: Government of the Precarious, trans. Aileen Derieg (London: Verso, 2015).

${ }^{33}$ Points which are made particularly well by recent Republican analyses of work. For the respective claims above, see: Anderson, Private Government; Alex Gourevitch, "Quitting Work but Not the Job: Liberty and the Right to Strike," Perspectives on Politics 14, no. 2 (2016): 307-23.

${ }^{34}$ Chamberlain, Undoing Work, 66; Lorey, State of Insecurity, 31.

${ }^{35}$ Thomas Biebricher, The Political Theory of Neoliberalism (Stanford: Stanford University Press, 2018), 42-46; Wendy Brown, Undoing the Demos: Neoliberalism's Stealth Revolution (New York: Zone Books, 2015), 36-38; Melinda Cooper, Family Values: Between Neoliberalism and the New Social Conservatism (New York: Zone Books, 2017); Stuart Hall, “The Neoliberal Revolution,” Soundings 48 (2011): 11.

${ }^{36}$ Lisa Adkins, "Social Reproduction in the Neoliberal Era: Payments, Leverage and the Minskian Household," Polygraph 27 (2019): 19-33; Tithi Bhattacharya, "How Not to Skip Class: Social Reproduction of Labor and the Global Working Class," in Social Reproduction Theory: Remapping Class, Recentering Oppression (London: Pluto Press, 2017), 90; Josh Bowsher, "Credit/Debt and Human Capital: Financialized Neoliberalism and the Production of Subjectivity," European Journal of Social Theory 22, no. 4 (2019): 513-32; Niamh Mulcahy, "Entrepreneurial Subjectivity and the Political Economy of Daily Life in the Time of Finance," European Journal of Social Theory 20, no. 2 (2017): 216-35.

${ }^{37}$ Gabriella Alberti et al., "In, Against and Beyond Precarity: Work in Insecure Times," Work, Employment and Society 32, no. 3 (2018): 447-57; Jan Breman, “A Bogus Concept?”, New Left Review 84 (2013): 130-38.

${ }^{38}$ The distinction between work and labor is a fraught question that we will not address here. The two terms are used interchangeably in the above.

${ }^{39}$ Mariarosa Dalla Costa and Selma James, The Power of Women and the Subversion of the Community (Bristol, UK: Falling Wall Press, 1975), 32-33.

${ }^{40}$ For an overview of disputes regarding the relationship between social reproductive labor and surplus value, see George Caffentzsis, In Letters of Blood and Fire: Work, Machines and the Crisis of Capitalism (Oakland, CA: PM Press, 2013), 252-72. In lieu of a wider overview of the history of social reproduction theory and its relationship to Marxist-Feminism, see Bhattacharya, Social Reproduction Theory; Susan Ferguson, "Building On the Strengths of the Socialist Feminist Tradition," Critical Sociology 25, no. 1 (1999): 1-15; Women and Work.

${ }^{41}$ Silvia Federici, Revolution at Point Zero: Housework, Reproduction, and Feminist Struggle (Oakland, CA: PM Press, 2012), 16.

42 Stella Rooney. "Can Automation End Women's "Double Burden?" Conter, July 11, 2019. https://www.conter.co.uk/blog/2019/7/10/can-tech-eradicate-womens-double-burden.

${ }^{43}$ Judy Wajcman, Feminism Confronts Technology (Philadelphia: Pennsylvania University Press, 1991), 106. For the classic account of the relationship between domestic technology and housework, see Ruth Schwarz Cohen, More Work for Mother: The Ironies of Household Technology from the Open Hearth to the Microwave, (New York: Basic Books, 1983).

${ }^{44}$ Lindsay B. Flynn and Herman Mark Schwartz, "No Exit: Social Reproduction in an Era of Rising Income Inequality," Politics \& Society 45, no. 4 (2017): 471-503; Ivis García, "The Two Income Debt Trap: Personal Responsibility and the Financialization of Everyday Life," Polygraph, no. 27 (2019): 35-53.

${ }^{45}$ A point that Angela Davis makes in criticism of the early social reproduction theory of the wages for housework movement: Women, Race and Class (London: Penguin, 2019).

${ }^{46}$ Shatema Threadcraft, Intimate Justice: The Black Female Body and the Body Politic (Oxford, UK: Oxford University Press, 2016), 128-130.

${ }^{47}$ Susan Ferguson, "Intersectionality and Social-Reproduction Feminisms: Toward an Integrative Ontology," Historical Materialism 24, no. 2 (2016): 53. 
${ }^{48}$ Indeed, the term "sex work" was adopted in an attempt to circumvent some of moral connotations of the term "prostitute." Carol Leigh, "Inventing Sex Work,"in Whores and Other Feminists, ed. Jill Nagle (London: Routledge, 1997), 225-31.

${ }^{49}$ Christine Overall, "What's Wrong with Prostitution? Evaluating Sex Work," Signs: Journal of Women in Culture and Society 17, no. 4 (1992): 705-24; Carole Pateman, The Sexual Contract (Stanford, CA: Stanford University Press, 1988), 189-219.

${ }^{50}$ Beloso, "Sex, Work, and the Feminist Erasure of Class."

${ }^{51}$ Mac and Smith, Revolting Prostitutes; R. Claire Snyder-Hall, "Third-Wave Feminism and the Defense of "Choice'," Perspectives on Politics 8, no. 1 (2010): 255-261.

${ }_{52}^{5}$ Mac and Smith, Revolting Prostitutes, 40-56.

${ }^{53}$ Pettinger, What's Wrong with Work?, 49-67. 